sensaciones de infancia, sino también en ciertas asociaciones propicias para dar a conocer aquellas y hasta en algunas figuras. Los Montrouge, gentes de mundo, ricas y desprejuiciadas, se asemejan a algunos de los personajes secundarios que pueblan, en confuso número, ios planos de atrás de las novelas de Proust. Este misterioso escritor que desde su despacho couatés se dedicó a volver del revés el tiempo perdido, como el dedo de un guante, preside muchas de las excursiones de Enrique Almada, es decir, de Ledesma Miranda, por los días infantiles. Esta influencia. justo es decirlo, no puede ser sino benéfica. Ledesma Miranda es un autor talentoso, capaz de infundir soplo personal a su obra a pesar de cuantas influencias puedan rodar en el ambiente.

Hay en Antes del mediodía muchos momentos felices, que acreditan a su autor de novelista hecho y derecho. La concisión y el equilibrio de frases como las siguientes:

Bajamos del coche. Se teñía de rosa un cielo bajo y las encinas plateaban. Yo había cortado una varita e iba deshojándola, mientras sentía los dedos impregnados de savia. De retorno, miraba clavarse a la fronda de la Moncloa los estoques de rosa del poniente y morir la tarde como un toro negro en una corrida apasionada (pág. 324),

no son insólitos en el transcurso total de este libro. La descripción de caracteres opuestos como el del padre y el de tío Juan es un acierto, comparable sólo al contraste entre la esDiritualidad ascendente de Luz y la rotunda materialidad de Mariana.
El ambiente del Colegio de jesuítas está muy bien dado, y sus visiones, aunque pocas, se clavan eń la memoria con un cortejo de figuras humanas variadas y bien definidas.

Con Ledesma Miranda, que forma parte de una juventud laboriosa e inquieta, se abre, pues, una nueva perspectiva para la novela española. De escritores como el autor de Antes del mediodia puede esperarse la reacción favorable que coloque a la novela peninsular en situación propicia para que salga a conquistar fama como en días más venturosos. R. Silva Castro.

El Puente de San Luis Rey, por Thornton Wilder.

El 20 de Julio de 1714 , a la hora del mediodía, el puente de San Luis Rey, situado en el camino real entre Lima y Cuzco, se quebró, precipitando al abismo a cinco personas que atravesaban por él de una orilla a otra del torrente. Dió la casualidad que uno de los testigos del accidente fuese el franciscano Fray Junípero, quien, en campaña evangelizadora por esa región, se disponía a pasar el puente.

Cualquier otro habríase dicho, con un secreto regocijo: ${ } \mathrm{DDiez}$ minutos más, y yo también...!’ Pero el pensamiento que acosó a Fray Junípero fué otro: ¿Por qué habrá ocurrido esto a estas cinco personas?

$\mathrm{Y}$ con esto tenemos el motivo de esta novela y la técnica de ella, pues el autor, aprovechando a Fray Ju- 
nípero, que se dedica a hacer investigaciones, narra la vida de cada una de las cinco personas que perecieron en el accidente: la Marquesa Doña María de Montemayor y su azafata Pepita: Manuel, un expósito; Tio Pio, especie de amigo de confianza y maestro de la Perrichola, y Jaime, hijo de ésta. Estos cinco personajes dan a Wilder materia para tres novelas cortas, tres novelas cortas en que describe no sólo la vida de cada uno de esos personajes, sino la vida de las personas que tienen relación con elias. Es así cómo en sus narraciones aparecen la Perrichola, el Virrey don Andrés de Ribera, y otros personajes más o menos históricos y más o menos fabulozos.

Habilísimo, el novelista yanqui ha hecho caso omiso del ambiente y del paisaje limeños, dedicándoles sólo dos o tres líneas que dan una idea general de ellos. Por lo demás, no se nota la ausencia de una descripción detallada. Los personajes atraen la atención del lector, haciéndole olvidar el escenario en que se mueven. De ellos, el mejor construido es Tío Pío, y el más interesante la Marquesa de Montemayor, aunque esta última, en quien el traductor de la obra, Ricardo Baeza, cree encontrar perfiles modificados de Madame de Sevigné, resulte demasiado interesante para la época y el ambiente limeños.

Los demás personajes, como la Perrichola, Manuel y Esteban, Pepita, el Virrey, están sobriamente delineados y viven en una atmósfera de claridad literaria muy precisa. La narración está hecha con seguridad y cada individuo corre hacia su destıno sin apresuramiento, deteniénAtenea-9 dose en cada uno de lcs acontecimientos y viviéndolos de la mejor o peor manera. $-M$. $R$.

\section{Estación. IdA Y vUELTA, por Rosa Chacel.}

Leímos este libro, con un poco de de sconfianza. Las mujeres de letras cuando adoptan novedades a! suso actual $>$ como la señorita Chacel caen, sin comprenderlas del todo, en la exageración, o más bien dicho, en la imitación del último procedimiento que les agrada. Así esta novela, como la llama su autora (1).

Consta de tres partes y son tres partes de un monólogo continuacio. sobre el que se extiende desde la primera página a la última, la influencia y más que la influencia, la sombra del inimitable Marcel Proust, a quien la autora, desgraciadamente, ha tratado de imitar muy de cerca. Decimos desgraciadamente, porque la señorita Chacel, sin la influencia proustiana quizá habría hecho un buen libro, pero en una señorita española de Valladolid, aficionada a la pintura, la lectura de Proust es algo así como una revolución al revés, en que sale a flote lo que debió quedar oculto y en que las mejores condiciones de escritora se deslíen en un anális's continuado de sensaciones y de estados de ánimo.... inexistentes. Porque en esto debe verse la diferencia de los imitadores con el maestro; en Proust los particularísimos estados de ánimo del autor con-

(1) Ediciones Ulises. Madrid, 1930. 